Maria Anna Kulikowska

Uniwersytet Mikołaja Kopernika, Toruń

\title{
Kształtowanie stosunków pomiędzy państwem a niekatolickimi związkami wyznaniowymi w drodze umów zawieranych na podstawie art. 25 ust. 5 Konstytucji Rzeczypospolitej Polskiej \\ i art. 8 zd. 3 Konstytucji Republiki Włoskiej
}

DOI: http://dx.doi.org/10.12775/SIT.2014.007

Republika Włoska i Rzeczpospolita Polska są państwami, których konstytucje oparto na modelu państwa świeckiego. Choć w ich ustawach zasadniczych nie umieszczono zapisów stanowiących o laickości państwa, to nie budzi wątpliwości, że można zasadę tę wyprowadzić z przepisów wyznaniowych w nich zawartych. Ponadto zarówno Polska, jak i Włochy są państwami, w których funkcjonuje rozdział państwa od Kościołów i innych związków wyznaniowych w wariancie separacji przyjaznej, nazywanej również skoordynowaną. Dowodem na liczne podobieństwa w sposobie regulacji kwestii konfesyjnych w konstytucjach polskiej i włoskiej jest bilateralizm w stosunkach ze związkami wyznaniowymi, a zwłaszcza w stosunkach z niekatolickimi związkami konfesyjnymi. Zasada współdziałania ze wspólnotami wyznaniowymi podkreślona jest przez przyznaną im autonomię wewnętrzną i status partnera $\mathrm{w}$ trakcie negocjacji $z$ władzami państwa w kwestii zawierania stosownych porozumień. 
Mimo że Polska jest państwem o tradycji katolickiej, to stosunkowo szybko przyjęła praktykę tolerancji religijnej. Już w podpisanym w 1573 roku akcie konfederacji warszawskiej pojawiła się bowiem gwarancja bezwarunkowego i wieczystego pokoju między wszystkimi wyznaniami ${ }^{1}$. Także Konstytucja 3 maja zapewniała wszystkim swobodę wyznania, mimo że uznała katolicyzm za religię panującą.

Kościół katolicki odegrał również istotną rolę w okresie zaborów, dlatego w Konstytucji marcowej z 1921 roku podkreślona została jego szczególna pozycja wśród wszystkich religii². Ustawa zasadnicza przewidywała równocześnie wolność sumienia i wyznania oraz równouprawnienie związków wyznaniowych.

Przyjazny stosunek państwa do związków konfesyjnych uległ jednak zmianie w okresie okupacji, kiedy naziści wprowadzili politykę nastawioną wrogo do religii. Podobnie było na ziemiach zajętych przez Związek Radziecki w 1939 roku. Ideologia antyreligijna utrzymała się także później w komunistycznej Polsce, gdy sytuacja Kościołów i związków wyznaniowych była trudna i polegała na ciągłych starciach ich przedstawicieli $z$ władzą. Poważne zmiany nastąpiły wraz z przemianami ustrojowymi w 1989 roku, kiedy w jednym czasie uchwalono aż trzy ustawy wyznaniowe ${ }^{3}$. Przedstawiciele Kościołów i związków konfesyjnych mieli wpływ nie tylko na kształt ustawodawstwa wyznaniowego, ale również na przepisy samej Konstytucji RP z 1997 roku$^{4}$. Nowa ustawa zasadnicza przyjęła w zakresie przepisów o charakterze wyznaniowym rozwiązania

${ }^{1}$ Konfederacja warszawska była pierwszym tego typu aktem w Europie, który gwarantował tolerancję religijną.

${ }^{2}$ W konstytucji tej znajduje się również klasyczne invocatio Dei: „W imię Boga Wszechmogącego!”.

${ }^{3}$ Ustawę o stosunku państwa do Kościoła katolickiego w polskiej Rzeczypospolitej Ludowej, ustawę o gwarancjach sumienia i wyznania oraz ustawę o ubezpieczeniu społecznym duchownych. Por. P. Borecki, C. Janik, Komisja Wspólna Przedstawicieli Rządu Rzeczypospolitej Polskiej i Konferencji Episkopatu Polski $w$ archiwaliach $z$ lat 1989-2010, Warszawa 2011, s. 5.

${ }^{4}$ Istotne było też uzgodnienie w 1993 roku tekstu nowego konkordatu i ratyfikowanie go w 1998 roku. 
kompromisowe; nie ma w niej invocatio $D e i^{5}$, zapewnione są jednak gwarancje wolności sumienia i wyznania oraz równouprawnienie Kościołów i związków wyznaniowych.

Podobnie jak Polska, również Włochy są państwem, w którym religia katolicka odgrywa istotną rolę, co jest spowodowane m.in. położeniem geograficznym Stolicy Apostolskiej. Aktem prawnym o szczególnym znaczeniu dla Republiki Włoskiej w dziedzinie relacji z Kościołami i związkami wyznaniowymi jest Statut albertyński z 1848 roku, który ustanowił tolerancję religijną i przyznał religii katolickiej status wyłącznej religii państwa ${ }^{6}$.

W 1870 roku $^{7}$ Państwo Kościelne utraciło swoją suwerenność terytorialną i niezależność wewnętrzną, których przywrócenie blokowali kolejni monarchowie. Skutkowało to licznymi konfliktami zaburzającymi ich wzajemne relacje. Poprawa stosunków z papiestwem stała się później ważnym postulatem dążącego do objęcia władzy Benito Mussoliniego, który rzeczywiście przywrócił niektóre przywileje religii katolickiej ${ }^{8}$. Wraz $z$ upływem czasu polityka faszystów uległa jednak zmianie i zaczęli znacząco ograniczać rolę religii w państwie.

${ }^{5}$ Znajdziemy jednak w preambule liczne nawiązania do religii. Konstytucję uchwalono „w poczuciu odpowiedzialności przed Bogiem lub przed własnym sumieniem”. Naród natomiast określony został jako wszyscy obywatele „wierzący w Boga będącego źródłem prawdy, sprawiedliwości, dobra i piękna, jak i nie podzielający tej wiary, a te uniwersalne wartości wywodzący z innych źródeł”. W preambule zamieszczono także wzmiankę o kulturze polskiej, która jest zakorzeniona „w chrześcijańskim dziedzictwie Narodu i ogólnoludzkich wartościach”. Jak widać, tekst konstytucji nie jest całkowicie wolny od nawiązań o charakterze religijnym, co tłumaczyć można polskimi tradycjami i uwarunkowaniami historycznymi.

${ }^{6}$ Por. L. Jamróz, Włochy, w: Systemy ustrojowe państw współczesnych, red. S. Bożyk, M. Grzybowski, Białystok 2012, s. 162.

${ }^{7}$ W 1870 roku Rzym został zdobyty przez wojska włoskie, a Papież Pius XI ogłosił się „więźniem Watykanu”.

${ }^{8}$ Np. nauczanie religii w szkołach państwowych, wieszanie krzyży w klasach i zniesienie obowiązku służby wojskowej dla duchownych. Por. E. Kozerska, Sytuacja Kościoła katolickiego $w$ faszystowskich Włoszech $w$ latach 1922-1939, w: Cuius regio, eius religio?, red. G. Górski, L. Ćwikła, M. Lipska, Lublin 2006, s. $289-314$. 
W 1929 roku negocjacje władz kościelnych i rządu doprowadziły ostatecznie do podpisania traktatów laterańskich ${ }^{9}$, które wyodrębniły zarówno politycznie, jak i terytorialnie państwo Watykan, uznały jego niezależność i niepodległość. Na mocy traktatów katolicyzm ponownie został uznany religią panującą we Włoszech. Przywileje nadane Kościołowi nie zmieniły jednak polityki faszystów, którzy wkrótce wrócili do rozszerzania kontroli nad Kościołem. Działalność innych związków wyznaniowych uzależniano od spełnienia licznych warunków, głównie dotyczących zgodności ich działań i obrzędów z porządkiem publicznym oraz dobrymi obyczajami $^{10}$. Ich działalność regulowana była przepisami ustawy o kultach dopuszczonych z 1929 roku $^{11}$ i dekretu królewskiego z 1930 roku $^{12}$, ograniczającego prawo budowania świątyń i miejsc kultu. Ograniczenia te były stopniowo rozszerzane, doszło nawet do tego, że władze państwowe zaczęły wywierać wpływ na obsadzanie stanowisk kościelnych i zobowiązały duchownych do składania przysięgi wierności państwu. Dyskryminacja dotyczyła nie tylko Kościoła katolickiego, ale również Kościoła zielonoświątkowców, Kościołów ewangelickich, mniejszości żydowskiej ${ }^{13}$ i innych związków wyznaniowych.

Po zakończeniu II wojny światowej, władzę w Republice objęła Chrześcijańska Demokracja, co w praktyce zacieśniło więzi Kościoła z polityką (mimo że oficjalnie odcinał się on od takich powiązań). W 1947 roku uchwalono Konstytucję Republiki Włoskiej ${ }^{14}$, z której przepisów Sąd Konstytucyjny wywiódł następnie naczelną zasadę

9 Traktaty laterańskie są grupą trzech aktów prawnych: traktatu, konwencji finansowej i konkordatu.

10 Por. P. Stanisz, Porozumienia $w$ sprawie regulacji stosunków między państwem i niekatolickimi zwiazkami wyznaniowymi we włoskim porzadku prawnym, Lublin 2007, s. 23-24.

11 Zob. Ustawa o kultach dopuszczonych, Legge n. 1159/1929 Disposizioni sull'esercizio dei culti ammessi nello Stato e sul matrimonio celebrato davanti ai ministri dei culti medesimi (GU 16-7-1929, n. 164).

12 Zob. Dekret królewski z 28 lutego 1930 roku, nr 289.

13 Por. P. Stanisz, Porozumienia $w$ sprawie regulacji, s. 23-24.

14 Zob.: A. Gaca, Z. Witkowski, Podstawy ustroju konstytucyjnego Republiki Włoskiej, Toruń 2012; L. Jamróz, Włochy, w: Systemy ustrojowe Państw Współczesnych, Bożyk S., Grzybowski M., Białystok 2012, s. 161-187; W. Or- 
świeckości państwa ${ }^{15}$. W 1984 roku wprowadzono także istotne zmiany w konkordacie ${ }^{16}$, które pomogły znormalizować stosunki państwa $z$ Kościołem.

\section{Rzeczpospolita Polska}

Zasada konsensualnej regulacji stosunków między państwem a Kościołami i innymi związkami wyznaniowymi zobowiązuje państwo, by w sprawach związanych $\mathrm{z}$ autonomią i niezależnością regulacja stosunków państwo-wspólnoty wyznaniowe nie przybierała postaci jednostronnej, lecz wynikała $z$ wcześniejszych uzgodnień ze stroną wyznaniową. Państwo musi przy tym zagwarantować faktyczne równouprawnienie związków konfesyjnych ${ }^{17}$.

Regulacja stosunków pomiędzy państwem a niekatolickimi związkami wyznaniowymi we współczesnej formie pojawiła się w prawie polskim na mocy art. $115 \mathrm{zd} .2$ konstytucji z 17 marca 1921 roku $^{18}$. Chociaż formalnie zagwarantowano w tym przepisie równoupraw-

łowski, W. Skrzydło, Ustrój polityczny Republiki Włoskiej, w: Ustroje państw współczesnych, red. W. Skrzydło, Lublin 2005, s. 55-92; P. Sarnecki, Ustroje konstytucyjne państw wspótczesnych, Warszawa 2013, s. 134-172; Z. Witkowski, Wejście $w$ życie Konstytucji Republiki Włoskiej, w: Wejście $w$ życie nowej Konstytucji Rzeczypospolitej polskiej. XXXIX Ogólnopolska Konferencja Katedr Prawa Konstytucyjnego. Księga Pamiątkowa, red. Z. Witkowski, Toruń 1998, s. 107-118; idem, System konstytucyjny Włoch, Toruń 2000; idem, Ustrój konstytucyjny współczesnych Włoch w aktualnej fazie jego przemian 1989-2004, Toruń 2004.

15 Por. F. Finocchiaro, Stato e Confessioni Religiose. Il Sistema Costituzionale, w: Enciclopedia Giuridica, Roma 1993, s. 2-3.

${ }^{16}$ Por. M. L. Lo Giacco, Una valutazione del Concordato tra Italia e Santa Sede a 25 anni dalla sua modificazione, w: Podstawy regulacji stosunków państwo-Kościół w Rzeczypospolitej Polskiej i Republice Włoskiej, red. P. Czarnek, D. Dudek, P. Stanisz, Lublin 2010, s. 125-145.

17 Por. K. Complak, Normy pierwszego rozdziału Konstytucji Rzeczypospolitej Polskiej, Wrocław 2007, s. 193-197.

18 „Stosunek Państwa do tych Kościołów i wyznań będzie ustalany w drodze ustawowej po porozumieniu się $z$ ich prawnemi reprezentacjami”. Zob. Ustawa z dnia 17 marca 1921 r. Konstytucja Rzeczypospolitej Polskiej, Dz.U. z roku 1921, Nr 44, poz. 267. 
nienie związków wyznaniowych, nie sposób zapomnieć o art. 114 Konstytucji marcowej, który wyraźnie przyznał wyznaniu rzymsko-katolickiemu „naczelne stanowisko wśród równouprawnionych wyznań"19. Tę swoistą deklarację interpretowano na dwa sposoby: jako zapis honorowy lub jako bezpośrednie przyznanie Kościołowi katolickiemu pozycji kościoła oficjalnego ${ }^{20}$. Trudno zaprzeczyć, że zapis tej treści spowodował rozróżnienie w pozycji poszczególnych związków wyznaniowych, wyraźnie dając pierwszeństwo Kościołowi katolickiemu.

Obecnie kwestię regulacji stosunków państwo-niekatolickie związki wyznaniowe reguluje natomiast art. 25 ust. 5 konstytucji z 2 kwietnia 1997 roku: „Stosunki między Rzecząpospolitą Polską a innymi kościołami oraz związkami wyznaniowymi określają ustawy uchwalone na podstawie umów zawartych przez Radę Ministrów z ich właściwymi przedstawicielami”. Inspiracją do takiego rozwiązania gwarancji równouprawnienia związków wyznaniowych, oprócz przepisów Konstytucji marcowej ${ }^{21}$, był również art. 8 Konstytucji Republiki Włoskiej (z 22 grudnia 1947 roku), który w zd. 3 mówi²2: „Ich [wyznań religijnych innych niż katolickich - M.K.] stosunki $z$ państwem są regulowane przez ustawę na podstawie porozumień Z właściwymi przedstawicielstwami" ${ }^{23}$. Obecnie prowadzenie spraw z zakresu stosunków między państwem a Kościołami i związkami wyznaniowymi należy do zadań Ministerstwa Administracji i Cyfryzacji, które wspiera organizacyjnie Komisję Wspólną Przedstawicieli

19 Ibidem.

20 Por. J. Krukowski, Polskie prawo wyznaniowe, Warszawa 2008, s. 39.

${ }^{21}$ W konstytucji z 1997 roku zagwarantowano pełne równouprawnienie związków wyznaniowych, które nie jest obciążone zapisem o naczelnym stanowisku Kościoła katolickiego na wzór Konstytucji marcowej.

22 Por. Z. Witkowski, Konstytucja Republiki Wtoskiej, Warszawa 2004; idem, Konstytucja Republiki Wtoskiej (stan prawny na dzień 1 lipca 2011 r.), w: Konstytucje państw Unii Europejskiej, red. W. Staśkiewicz, Warszawa 2011. Tekst konstytucji w języku włoskim jest dostępny na stronie internetowej Senatu Republiki Włoskiej www.senato.it. Natomiast w tłumaczeniu Zbigniewa Witkowskiego na język polski jest dostępny w na stronie internetowej Biblioteki Sejmowej www.bs.sejm.gov.p (dostęp: 1 kwietnia 2014 r.).

${ }^{23}$ Zob. Konstytucja Republiki Włoskiej z 27 grudnia 1947 roku, Gazzetta Ufficiale della Repubblica Italiana del 1947, nr 298. 
Rządu i Konferencji Episkopatu oraz wspólne komisje rządu i władz innych Kościołów i związków wyznaniowych.

Sposób kształtowania stosunków państwa $z$ poszczególnymi związkami wyznaniowymi nie jest jednakowy, istotną rolę odgrywa w tej materii specyfika konkretnych wyznań. Różnorodnością związków wyznaniowych tłumaczyć można np. odmienny tryb regulowania stosunków $z$ Kościołem katolickim. Państwo reguluje swoje stosunki $z$ nim w drodze umowy zawartej ze Stolicą Apostolską ${ }^{24}$ i ustaw ${ }^{25}$. Umowa tama postać konkordatu - umowy międzynarodowej ratyfikowanej na podstawie uprzedniej zgody wyrażonej w ustawie. Stolica Apostolska jest suwerennym państwem i podmiotem prawa międzynarodowego. Odróżnia to Kościół katolicki od innych związków wyznaniowych. Zgodnie z treścią art. 91 konstytucji konkordat stanowi część krajowego porządku prawnego, a jego przepisy mogą być bezpośrednio stosowane ${ }^{26}$. Choć w praktyce ustalenia wynikające $z$ przepisów konkordatu są przenoszone na inne związki wyznaniowe, nie można uznać tej praktyki za naruszenie zasady równouprawnienia, ponieważ każdy $z$ nich ma prawo negocjować inne warunki podczas zwierania umowy z Radą Ministrów.

Relacje między państwem a pozostałymi związkami wyznaniowymi są natomiast określane w postaci ustaw uchwalanych na podstawie umów zawieranych przez Radę Ministrów z przedstawicielami poszczególnych związków wyznaniowych o uregulowanej sytuacji prawnej, a więc wpisanymi do rejestru Kościołów i innych związków wyznaniowych (tzw. ustawy indywidualne). Umowy te nie mają charakteru normatywnego. Niezarejestrowanym związkom wyznaniowym, niezależnie od liczby członków, których zrzeszają, nie przysługuje prawo zawarcia umowy z Radą Ministrów. Nie

${ }^{24}$ Zob. Konkordat między Stolicą Apostolską i Rzecząpospolitą Polską, podpisany w Warszawie dnia 28 lipca 1993 r., Dz.U. z 1998 r., Nr 51, poz. 318.

${ }^{25}$ Ustawy zawierane na podstawie art. 25 ust. 4 mają funkcję pomocniczą i muszą być zgodne $z$ treścią konkordatu. Przykładem takiego aktu normatywnego jest Ustawa o stosunku Państwa do Kościoła Katolickiego w Rzeczypospolitej Polskiej z 17 maja 1989 roku, Dz.U. Nr 29, poz. 154, ze zm.

${ }^{26}$ Por. P. Stanisz, Stosunki między państwem a kościołami $i$ innymi związkami wyznaniowymi w Rzeczypospolitej Polskiej-zarys problematyki, w: Podstawy regulacji stosunków państwo-Kościót, s. 28-30. 
jest zatem możliwa regulacja ich stosunków z państwem w drodze ustawowej.

Rada Ministrów jest zobowiązana do negocjowania umów z poszczególnymi związkami wyznaniowymi w sytuacji, gdy wyrażą chęć przystąpienia do rozmów w tej materii. Umowa zawarta $z$ właściwym przedstawicielstwem musi być podstawą uchwalonej następnie z inicjatywy Rady Ministrów ustawy ${ }^{27}$. O konsekwencjach nieprzystąpienia Rady Ministrów do negocjacji pisze Arkadiusz Januchowski. Jest kilka opinii na temat odpowiedzialności Rady Ministrów za zaniechanie podjęcia negocjacji. Za najbardziej słuszny należy uznać pogląd o możliwości wniesienia skargi do Wojewódzkiego Sądu Administracyjnego ${ }^{28}$.

Parlament uchwala ustawę o stosunku państwa do danego związku wyznaniowego w normalnym trybie ustawodawczym. Może w związku $z$ tym zostawić projekt bez rozpatrzenia albo go odrzucić. Nie może jednak wprowadzić poprawek i uchwalić ustawy, ponieważ każda poprawka (inna niż redakcyjna) wprowadzona na tym etapie, musi zostać zaakceptowana w umowie ze związkiem wyznaniowym ${ }^{29}$.

Zarówno Radzie Ministrów, jak i związkom konfesyjnym posiadającym już ustawy indywidualne przysługuje prawo renegocjowania treści umowy, co prowadzi do konieczności wprowadzenia poprawek do ustawy. Prawo renegocjowania treści umowy dotyczy również Kościoła katolickiego w odniesieniu do konkordatu. Pozostałe umowy regulujące sytuację prawną Kościoła katolickiego w Polsce nie są oparte na wcześniejszych umowach i mogą być zmieniane jednostronnie przez Parlament.

Sejm i Senat mają kompetencję w zakresie wprowadzania poprawek do projektu ustawy (innych niż redakcyjne) oraz nowelizacji tylko po zawarciu odpowiedniego porozumienia $z$ reprezentacją związku wyznaniowego albo na podstawie upoważnienia zawartego

27 Por. Z. Witkowski, Opinia $w$ sprawie zagadnień prawnych wynikajacych $z$ art. 25 ust. 5 Konstytucji, „Przegląd Legislacyjny” 2002, nr 24, s. 99-104.

${ }_{28}$ Por. A. Januchowski, Zagadnienia zwiazane $z$ interpretacją art. 25 ust. 4 i 5 Konstytucji RP, „Studia z Prawa Wyznaniowego” 2007, t. 10, s. 273-276.

${ }^{29}$ Por. Z. Witkowski, Opinia w sprawie zagadnień prawnych, s. 99-104. 
we wcześniej zawartej umowie ${ }^{30}$. Zdaniem Piotra Mikuli, ograniczenie Parlamentu w tym zakresie, jest spowodowane potrzebą zrównania w świetle prawa wszystkich związków wyznaniowych, a przede wszystkim próbą upodobnienia procesu powstawania ustaw indywidualnych do procedury zawierania konkordatu ${ }^{31}$.

Niekatolickimi związkami wyznaniowymi o uregulowanej ustawowo sytuacji prawnej wpisanymi do rejestru Kościołów i związków wyznaniowych oraz posiadającymi osobowość prawną są: Wschodni Kościół Staroobrzędowy ${ }^{32}$, Muzułmański Związek Religijny $^{33}$, Karaimski Związek Religijny ${ }^{34}$, Polski Autokefaliczny Kościół Prawosławny ${ }^{35}$, Kościół Ewangelicko-Augsburski ${ }^{36}$, Kościół Ewnagelicko-Reformowany ${ }^{37}$, Kościół Polskokatolicki w Rzeczypospolitej Polskiej ${ }^{38}$, Kościół Adwentystów Dnia Siódmego ${ }^{39}$, Kościół Chrześcijan

30 Ibidem.

${ }^{31}$ Por. P. Leszczyński, Dualny (umowny i ustawowy) tryb regulacji stosunków między państwem a nierzymskokatolickimi wspólnotami religijnymi na podstawie art. 25 ust. 5 Konstytucji RP, w: Bilateralizm w stosunkach państwowo-kościelnych, red. M. Bielecki, Lublin 2011, s. 257.

${ }^{32}$ Zob. Rozporządzenie Prezydenta Rzeczypospolitej z dnia 22 marca 1928 r. o stosunku Państwa do Wschodniego Kościoła Staroobrzędowego, nie posiadającego hierarchji duchownej, Dz.U. Nr 38, poz. 363, ze zm.

${ }^{33}$ Zob. Ustawa $\mathrm{z}$ dnia 21 kwietnia 1936 r. o stosunku Państwa do $\mathrm{Mu}$ zułmańskiego Związku Religijnego w Rzeczypospolitej Polskiej, Dz.U. Nr 30, poz. 240, ze zm.

${ }^{34}$ Zob. Ustawa z dnia 21 kwietnia 1936 r. o stosunku Państwa do Karaimskiego Związku Religijnego w Rzeczypospolitej Polskiej, Dz.U. Nr 30, poz. 241, ze $\mathrm{zm}$.

${ }^{35}$ Zob. Ustawa $z$ dnia $z$ dnia 4 lipca 1991 r. o stosunku Państwa do Polskiego Autokefalicznego Kościoła Prawosławnego, Dz.U. Nr 66, poz. 287, ze zm.

${ }^{36}$ Zob. Ustawa z dnia 13 maja 1994 r. o stosunku Państwa do Kościoła Ewangelicko-Augsburskiego w Rzeczypospolitej Polskiej, Dz.U. Nr 73, poz. 323, ze $\mathrm{zm}$.

${ }^{37}$ Zob. Ustawa $\mathrm{z}$ dnia 13 maja 1994 r. o stosunku Państwa do Kościoła Ewangelicko-Reformowanego w Rzeczypospolitej Polskiej, Dz.U. Nr 73, poz. 324, ze $\mathrm{zm}$.

${ }^{38}$ Zob. Ustawa z dnia 30 czerwca 1995 r. o stosunku Państwa do Kościoła Polskokatolickiego w Rzeczypospolitej Polskiej, Dz.U. Nr 97, poz. 482, ze zm.

${ }^{39}$ Zob. Ustawa z dnia 30 czerwca 1995 r. o stosunku Państwa do Kościoła Adwentystów Dnia Siódmego w Rzeczypospolitej Polskiej, Dz.U. Nr 97, poz. 481, ze zm. 
Baptystów ${ }^{40}$, Kościół Ewangelicko-Metodystyczny ${ }^{41}$, Starokatolicki Kościół Mariawitów ${ }^{42}$, Kościół Zielonoświątkowy ${ }^{43}$, Kościół Katolicki Mariawitów $^{44}$ oraz Związek Gmin Wyznaniowych Żydowskich ${ }^{45}$.

Sytuacja pozostałych związków wyznaniowych jest natomiast regulowana przepisami ustawy o gwarancjach wolności sumienia i wyznania z 17 maja 1989 roku i opiera się na rejestracji związku. Istnieją zatem trzy rodzaje regulacji stosunków związku wyznaniowego $\mathrm{z}$ państwem: konkordatowo-ustawowy, umowno-ustawowy oraz rejestracyjny ${ }^{46}$.

Chociaż ustaw zawartych ze związkami wyznaniowymi innymi niż Kościół katolicki jest tylko 14, to wszystkie inne zarejestrowane związki wyznaniowe mają prawo zawierania umów z państwem na podstawie art. 25 ust. 5 konstytucji. Dotychczasowe ustawy dotyczące relacji Rzeczypospolitej Polskiej z niekatolickimi związkami wyznaniowymi, zostały zawarte przed wejściem w życie przepisów konstytucji z 1997 roku. Wynika z tego, że w praktyce legislacyjnej art. 25 ust. 5 jest przepisem martwym i nie znalazł jeszcze zastosowania w stosunku do konkretnego związku wyznaniowego ${ }^{47}$.

${ }^{40}$ Zob. Ustawa z dnia 30 czerwca 1995 r. o stosunku Państwa do Kościoła Chrześcijan Baptystów w Rzeczypospolitej Polskiej, Dz.U. Nr 97, poz. 480, ze zm.

${ }^{41}$ Zob. Ustawa $z$ dnia 30 czerwca 1995 r. o stosunku Państwa do Kościoła Ewangelicko-Metodystycznego w Rzeczypospolitej Polskiej, Dz.U. Nr 97, poz. 479, ze zm.

${ }^{42}$ Zob. Ustawa z dnia 20 lutego 1997 r. o stosunku Państwa do Kościoła Starokatolickiego Mariawitów w Rzeczypospolitej Polskiej, Dz.U. Nr 41, poz. 253, ze $\mathrm{zm}$.

${ }^{43}$ Zob. Ustawa z dnia 20 lutego 1997 r. o stosunku Państwa do Kościoła Zielonoświątkowego w Rzeczypospolitej Polskiej, Dz.U. Nr 41, poz. 254, ze zm.

${ }^{44}$ Zob. Ustawa z dnia 20 lutego 1997 r. o stosunku Państwa do Kościoła Katolickiego Mariawitów w Rzeczypospolitej Polskiej, Dz.U. Nr 41, poz. 252, ze zm.

${ }^{45}$ Zob. Ustawa z dnia 20 lutego 1997 r. o stosunku Państwa do gmin wyznaniowych żydowskich w Rzeczypospolitej Polskiej, Dz.U. Nr 41, poz. 251, ze zm.

${ }^{46}$ Zob. A. Januchowski, op.cit., s. 261-279.

47 Warto podkreślić, że w rejestrze jest aż 158 Kościołów i związków wyznaniowych o uregulowanej sytuacji prawnej. Zob. Spis „Kościoły i związki wyznaniowe wpisane do rejestru kościołów i innych związków wyznaniowych" opublikowany 14 stycznia 2013 roku i umieszczony na stronie internetowej Ministerstwa Administracji i Cyfryzacji www.mac.gov.pl/wp-content/uploads/2011/12/e-rejestr2.pdf (dostęp: 1 kwietnia 2014 r.). 
Jednym $z$ powodów, dla których mniejsze wspólnoty wyznaniowe nie chcą organizować swojej działalności w drodze ustaw indywidualnych, może być funkcjonalność uregulowań zawartych w ustawie o gwarancjach wolności sumienia i wyznania. Przepisy tej ustawy są znacznie nowocześniejsze niż np. uregulowania zawarte we włoskiej ustawie o kultach dopuszczonych, która wymaga istotnych reform.

Trudno mówić o pasywności Rady Ministrów w kwestii porozumień, ponieważ chęć zawarcia umowy musi wynikać $z$ woli dwóch stron. Można jednak przypuszczać, że mechanizm zawierania wspomnianych umów znajdzie szerokie zastosowanie w niedługiej przyszłości w związku $\mathrm{z}$ wprowadzaniem systemu odpisu od podatku dochodowego na rzecz Kościoła lub związku wyznaniowego $(0,5 \%)^{48}$.

Temat wprowadzenia nowych regulacji w zakresie finansowania związków wyznaniowych zaczął być dyskutowany po exposé premiera Donalda Tuska 18 listopada 2011 roku, w którym poruszył kwestię likwidacji Funduszu Kościelnego, nawet kosztem wprowadzenia ewentualnych zmian w konkordacie ${ }^{49}$. Trzeba stwierdzić, że aktualnie obowiązujące rozwiązania prawne nie odpowiadają

${ }^{48}$ Jest to kolejny dowód na to, że polski ustawodawca wzoruje się w kwestiach relacji państwa $z$ Kościołami i związkami wyznaniowymi na doświadczeniach włoskich. Tak skonstruowany system asygnaty podatkowej jest bowiem w dużej mierze oparty na funkcjonującej w Republice Włoskiej instytucji otto per mille, czyli na odpisie 0,8\% podatku dochodowego na rzecz państwa, Kościoła lub związku wyznaniowego. Podobny system funkcjonuje też np. w Hiszpanii i na Węgrzech. Zob. M. Kulikowska, Otto per mille-włoski system finansowania związków wyznaniowych, „Toruńskie Studia Polsko-Włoskie” 2012, z. 8, s. 47-56.

${ }^{49}$ Zasadniczo konkordat $\mathrm{z} 1993$ roku przekazuje regulację kwestii finansowych specjalnej komisji, o której mowa w art. 22 ust. 2 i 3 tego aktu. W związku z tym w 1998 roku rzeczywiście powstały Komisje Konkordatowe: Rządowa i Kościelna, które powołały zespoły robocze mające za zadanie wypracować projekty dokumentów. Przez ponad 10 lat nie wypracowały jednak żadnego projektu. Obecnie regulacja stosunków finansowych leży w zasadzie po stronie państwa (Rada Ministrów uznała się za właściwą w tych kwestiach za zgodą Kościoła, który zaakceptował Deklarację RM z 15 kwietnia 1997 roku w sprawie zapewnienia jasnej wykładni przepisów Konkordatu między Stolicą Apostolską a Rzecząpospolitą Polską, podpisanego w Warszawie w dniu 28 lipca 1993 r.). 
potrzebom nowoczesnego społeczeństwa demokratycznego, a zwolennikiem wprowadzenia gruntownych reform był nie tylko Rząd, ale i Kościół katolicki, który zrzesza największą liczbę wiernych w Polsce ${ }^{50}$. Próba wprowadzenia systemu asygnaty podatkowej jednocześnie na rzecz wszystkich związków wyznaniowych odróżnia Polskę od Włoch, które system otto per mille wprowadziły najpierw jako mechanizm finansowania Kościoła katolickiego, a dopiero później rozpoczęły rozmowy $z$ pozostałymi związkami wyznaniowymi ${ }^{51}$ w celu umożliwienia im przystąpienia do niego oraz zapewnienia równości wobec prawa różnym religiom, stosownie do art. 3 konstytucji ${ }^{52}$. W Polsce został już sporządzony projekt ustawy o zmianie ustawy o gwarancjach wolności sumienia i wyznania oraz niektórych innych ustaw ${ }^{53}$. Zgodnie $z$ jego treścią o udział w podziale środków uzyskanych z odpisu ubiegać się będą mogły wyłącznie Kościoły

We Włoszech w celu wprowadzenia podobnych reform powołano specjalną komisję, polska Rada Ministrów postanowiła jednak prowadzić rozmowy z Kościołem rzymskokatolickim bez powoływania takiej komisji, a strona kościelna nie oponowała.

${ }^{50}$ Kościół katolicki ma również największy budżet wśród wszystkich związków wyznaniowych w Polsce. Metropolita Warszawski kard. Kazimierz Nycz w ramach realizacji postulatu większej jawności finansowej ujawnił, że budżet ten wynosi ok. 8 mld zł rocznie. Z badań tygodnika „Wprost” wynika, że na tę sumę składa się: 1 mld zł z ofiar składanych na tacę, 4,5 mld zł z innych ofiar, 0,5 mld zł z działalności gospodarczej, 1 mld zł z prowadzenia lekcji religii w szkołach, 0,4 mld zł z innych dofinansowań z budżetu państwa i $90 \mathrm{mln}$ zł z Funduszu Kościelnego. Por. A. Dzierżanowski, Z czego żyje Kościół, „Wprost” 13-19 maja 2013, s. 34-38.

51 Tak prowadzone prace nad wprowadzeniem asygnaty podatkowej mogły sprawiać wrażenie dyskryminacji związków wyznaniowych innych niż Kościół Rzymskokatolicki.

52 Por. C. Cardia, Stato e confessioni religiose. Il Regime Finanziario, w: Enciclopedia Giuridica, s. 3.

53 Projekt został już poddany konsultacjom społecznym i uzgodnieniom międzyresortowym. Niestety w konsultacjach społecznych głos zabrało jedynie 63 obywateli, a sam projekt trzeba uznać za propozycję niewykorzystującą w pełni dorobku innych państw w tej dziedzinie. Wiele rozwiązań, które wydają się korzystnie wpływać na funkcjonowanie otto per mille we Włoszech, nie zostało bowiem powtórzonych w polskiej propozycji. Jednym $z$ nich jest zastosowane we Włoszech obliczanie średniego wpływu z odpisu od podatku dochodowego obywateli, dzięki któremu związek wyznaniowy dostaje taką samą 
i związki wyznaniowe o sytuacji prawnej uregulowanej w drodze ustawowej ${ }^{54}$. Z pewnością wpłynie to na większą aktywność związków konfesyjnych w kwestii zawierania stosownych porozumień. W pewnym sensie podobny proces przeszła Republika Włoska po wejściu w życie przepisów o otto per mille. W przeciągu kilku zaledwie lat liczba porozumień zawieranych przez Kościoły i związki wyznaniowe $z$ państwem wyraźnie wówczas wzrosła, ponieważ porozumienie było jednym $z$ warunków przystąpienia do rozdziału uzyskanych $z$ odpisu środków. Biorąc pod uwagę doświadczenia włoskie, wydaje się zatem mało prawdopodobne, by w przyszłości nadal tylko 15 polskich Kościołów i związków wyznaniowych (które zawarły wcześniej umowy) było zainteresowanych uczestniczeniem $\mathrm{w}$ podziale pieniędzy zebranych $\mathrm{z}$ odpisu. Niestety prace związane w wprowadzeniem nowego systemu finansowania Kościołów i związków wyznaniowych trwają od 2012 roku i przynoszą niewielkie rezultaty, a zakładana wyjściowo data wprowadzenia nowych rozwiązań w życie była już kilkukrotnie przekładana ${ }^{55}$.

ilość pieniędzy od każdej osoby, która zdecyduje się dokonać odpisu na jego korzyść. Pozwala to uniknąć sytuacji, w których związki wyznaniowe preferują pozyskiwanie odpisu od zamożnych wiernych, zamiast skupiać się na przekonaniu jak największej liczby osób do wsparcia ich w ten sposób. Zob. projekt ustawy o zmianie ustawy o gwarancjach wolności sumienia i wyznania oraz niektórych innych ustaw, www.mamzdanie.org.pl/web/guest/konsultacje/-/ message_boards/message/34283 (dostęp: 1 kwietnia 2014 r.).

54 „Przepis art. 5b ust. 2 określa przesłanki, które kościół lub inny związek wyznaniowy musi spełniać, aby mógł zostać wpisany do wykazu. Projekt zakłada, że wykaz kościołów i innych związków wyznaniowych, na rzecz których może być przekazywane 0,5\% podatku dochodowego od osób fizycznych, uwzględniał będzie Kościoły i inne związki wyznaniowe o uregulowanej sytuacji prawnej nieprzerwanie od co najmniej 3 lat. Na gruncie projektowanej zmiany do ustawy, przez uregulowaną sytuację prawną Kościoła lub innego związku wyznaniowego należy rozumieć funkcjonowanie przez Kościół lub inny związek wyznaniowy na podstawie partykularnej ustawy o stosunku Państwa do Kościoła albo innego związku wyznaniowego albo wpisu do rejestru Kościołów i innych związków wyznaniowych”. Por. Uzasadnienie szczegółowe projektu ustawy o zmianie ustawy o gwarancjach wolności sumienia i wyznania oraz niektórych innych ustaw, s. 14.

${ }^{55}$ Informacje o aktualnych pracach nad projektem można znaleźć na stronie internetowej Ministerstwa Administracji i Cyfryzacji www.mac.gov.pl. 
Dopiero zawarcie przez Radę Ministrów umowy z reprezentacją związku wyznaniowego stwarza sytuację, w której dopuszczalne jest wydanie ustawy. Ustawa uchwalona $z$ inicjatywy Rady Ministrów $^{56}$, ale bez uprzedniego porozumienia ze związkiem wyznaniowym, powinna zostać uznana za niezgodną z konstytucją przez Trybunał Konstytucyjny. Co więcej, ustawa powinna czynić zadość postanowieniom umowy. Zdaniem Pawła Leszczyńskiego ostatnim postanowieniem umowy, o której mowa, powinno być „zobowiązanie Rady Ministrów do wniesienia projektu ustawy do Sejmu”, najlepiej z klauzulą pilności ${ }^{57}$. Trybunał Konstytucyjny będzie władny zbadać konstytucyjność ustawy uchwalonej wbrew postanowieniom umowy albo zawierającej niewynikające $z$ niej postanowienia ${ }^{58}$.

\section{Republika Włoska}

Kształtowanie stosunków pomiędzy państwem a niekatolickimi związkami wyznaniowymi w drodze porozumień ze związkami konfesyjnymi jest w odniesieniu do Republiki Włoskiej bardzo interesujące ze względu na fakt, że wcześniej była ona państwem wyznaniowym. Akty pochodzące $z$ lat 1929-1930 uczyniły Włochy państwem, w którym wyznanie rzymskokatolickie było religią państwową. Działalność pozostałych związków wyznaniowych zależała od spełnienia dodatkowych kryteriów ${ }^{59}$, była też w poważny sposób ograniczana przez władze, które wprowadziły różnice w traktowaniu poszczególnych związków konfesyjnych.

${ }^{56}$ O wyłącznej inicjatywie Rady Ministrów w tej kwestii pisał P. Mikuli, Ustawy o ograniczonym zakresie przedmiotowym $w$ systemie źródeł prawa $w$ Polsce. Uwagi porzadkujace, „Przegląd Sejmowy” 2012, nr 5 (112), s. 44-47.

57 Por. P.A. Leszczyński, [rec.] M. Olszówka, Ustawy wyznaniowe. Art. 25 ust. 5 Konstytucji RP - próba interpretacji, Warszawa 2010, s. 96, „Przegląd Sejmowy" 2011, nr 5 (106), s. 207-210.

58 Por. L. Garlicki, Komentarz do art. 25, w: Konstytucja Rzeczypospolitej Polskiej. Komentarz, red. L. Garlicki, t. 5, Warszawa 2007, s. 22-24.

59 Por. P. Stanisz, Porozumienia $w$ sprawie, s. 24. 
Status Kościoła katolickiego we Włoszech zmienił tzw. nowy konkordat ze Stolicą Apostolską zawarty 18 lutego 1984 roku $^{60}$. W art. 1 protokołu dodatkowego uchylono moc obowiązującą zasady, że wyznanie katolickie jest religią państwową. Wprowadzono nowy, kompleksowy system, co doprowadziło do stabilizacji stosunków państwa i Kościoła katolickiego ${ }^{61}$. Pojawiły się również nowe instytucje (np. małżeństwo konkordatowe). Mimo wszystko wiele kwestii celowo pozostawiono do szczegółowego uregulowania w drodze osobnych porozumień. W ten sposób wprowadzono m.in. nowy sposób finansowania związków wyznaniowych w postaci asygnaty podatkowej (tzw. otto per mille). Choć wyjściowo system ten został stworzony po to, by usystematyzować finansowanie wyłącznie Kościoła katolickiego, z czasem okazało się, że bazując na porozumieniach pomiędzy Stolicą Apostolską a państwem, można rozszerzyć funkcjonowanie tych instytucji także na inne związki wyznaniowe ${ }^{62}$.

Instytucjonalnym relacjom państwo-Kościoły i inne związki wyznaniowe poświęcono dwa przepisy Konstytucji Republiki Włoskiej z 1947 roku: art. 7 i 8. Podobnie do Konstytucji Rzeczypospolitej Polskiej z 1997 roku, włoska konstytucja także zawiera w swoich przepisach zasadę bilateralności, która stanowi gwarancję wolności religijnej. Różnicą w porównaniu z rozwiązaniami przyjętymi w Polsce jest wyłączenie regulacji stosunków państwo-Kościół katolicki do osobnego przepisu - poświęcono im art. 7. Relacje państwa z niekatolickimi związkami wyznaniowymi są natomiast uregulowane w art. 8 ustawy zasadniczej.

Przez pewien czas norma $z$ art. 8 zd. 3 była (podobnie jak w Polsce) martwym przepisem. Pierwszym związkiem wyznaniowym, który zawarł na jego podstawie porozumienie $\mathrm{z}$ państwem, był Ewangelicki Kościół Waldensów w 1984 roku. Stopniowo jednak więcej związków konfesyjnych zawarło podobne porozumienia.

${ }^{60}$ Jego przepisy wprowadzono do włoskiego porządku prawnego na podstawie ustawy nr 121 z 25 marca 1984 roku.

${ }^{61}$ Por. G. Dammacco, Le relazioni tra lo Stato e Chiesa nella esperienza italiana, w: Podstawy regulacji stosunków państwo-Kościót, s. 41-57.

62 Por. C. Cardia, op.cit., s. 3. 
Zasada równouprawnienia związków wyznaniowych została wyrażona $\mathrm{w}$ art. 8 konstytucji, podkreślono w nim również zerwanie $z$ ideą państwa wyznaniowego. Przepis ten reguluje sytuację wszystkich wyznań, także katolickiego. Wynika $z$ niego obowiązek traktowania przez państwo wszystkich związków wyznaniowych w ten sam sposób. Ze względu na różnorodność związków konfesyjnych, szczegółowe regulacje powinny jednak uwzględniać ich specyfikęer3. $Z$ jednej strony państwo nie może prowadzić działalności dyskryminacyjnej, $z$ drugiej natomiast nie powinno traktować wszystkich związków wyznaniowych w sposób identyczny, ponieważ różnią się one między sobą. W związku $z$ tym, jeśli różnice można wytłumaczyć specyfiką danego związku, regulacje odnoszące się do poszczególnych wyznań nie muszą być dokładnie takie same.

Artykuł 7 konstytucji mówi, że „Państwo i Kościół katolicki są, każde we własnym zakresie, niezależne i suwerenne"64. Taka regulacja, podobnie jak w Konstytucji Rzeczypospolitej Polskiej, wynika ze szczególnego charakteru Kościoła katolickiego, będącego podmiotem prawa międzynarodowego ${ }^{65}$. „Niezależność i suwerenność”, o której ustawa zasadnicza wspomina w odniesieniu do Kościoła katolickiego w art. 7, nie dotyczy pozostałych związków wyznaniowych, chociaż należy im przyznać prawo do autonomii i niezależności w zakresie ich spraw statutowych. Mają one bowiem prawo organizowania się według własnych przepisów. Jedynym ograniczeniem jest w tym przypadku zgodność z włoskim porządkiem prawnym (art. 8). Państwo może zatem regulować sytuację tych związków wyznaniowych, o ile nie ingeruje w ich statuty ${ }^{66}$.

${ }^{63}$ Por. F. Finocchiaro, op.cit., s. 4.

${ }^{64}$ Por. Z. Witkowski, Konstytucja Republiki Włoskiej, Warszawa 2004.

65 Stosunki Republiki z Kościołem katolickim są regulowane przez Pakty laterańskie. Wprowadzenie do Paktów zmian, które zostały przyjęte przez obie strony, nie wymaga rewizji konstytucji.

${ }^{66}$ Por. P. Stanisz, Porozumienia $w$ sprawie regulacji, s. 56; idem, Proces normowania stosunków pomiędzy państwem a niekatolickimi związkami wyznaniowymi $w$ trybie art. 8 ust. 3 Konstytucji Republiki Wtoskiej z 1947 r. (ujęcie historyczne), „Studia z Prawa Wyznaniowego” 2006, t. 9, s. 27-50. 
Relacje państwa $z$ pozostałymi związkami wyznaniowymi regulowane są przez ustawy wydawane na podstawie porozumień $z$ przedstawicielstwami konkretnych związków. Obecnie prowadzenie spraw z zakresu stosunków między Państwem a Kościołami i związkami wyznaniowymi należy do zadań Ministerstwa Spraw Wewnętrznych (Ministero dell'Interno).

Propozycja zawarcia porozumienia przez związek wyznaniowy jest przedkładana do zaopiniowania Ministerstwu Spraw Wewnętrznych, a dokładniej - działającej w ramach Departamentu Wolności Cywilnoprawnej i Imigracji (Dipartimento per le libertà civili e l'immigrazione), Dyrekcji Centralnej do spraw Wyznań (Direzione Centrale degli affari dei culti). Samo przystąpienie do negocjacji i zawarcie porozumienia $z$ reprezentacją związku wyznaniowego należy natomiast do kompetencji Rady Ministrów.

Zainteresowany związek wyznaniowy musi skierować formalny wniosek o zawarcie porozumienia do Prezesa Rady Ministrów, który zwyczajowo deleguje prowadzenie negocjacji z przedstawicielstwami związków wyznaniowych Podsekretarzowi Rady Ministrów. Warunkiem przychylnego rozpatrzenia wniosku i podjęcia negocjacji jest posiadanie przez związek wyznaniowy osobowości prawnej zgodnie z przepisami ustawy z 1929 roku $^{67}$.

Organem pomocniczym Podsekretarza jest Międzyministerialna Komisja Porozumień ze Związkami Wyznaniowymi (Commissione interministeriale per le intese con le Confessioni religiose), która przygotowuje wstępną wersję porozumienia, zgodną z ustaleniami dokonanymi $z$ właściwym przedstawicielstwem związku konfesyjnego. Na temat wstępnej wersji porozumienia swoją opinię wyraża Komisja Doradcza do spraw Wolności Religijnej (Commissione consultiva per la libertà religiosa).

Po zakończeniu konsultacji porozumienie podpisane przez Podsekretarza oraz przez przedstawicielstwo związku wyznaniowego zostaje poddane procedurze zatwierdzającej w Radzie Ministrów, która kończy się złożeniem podpisu przez Prezesa Rady Ministrów. Po podpisaniu porozumienia przez premiera i reprezentację związku

${ }^{67}$ Zob. Ustawa o kultach dopuszczonych, Legge n. 1159/1929. 
wyznaniowego porozumienie zostaje przekazane Parlamentowi w celu uchwalenia ustawy indywidualnej na jego podstawie.

Porozumienia, które ostatecznie doprowadziły do uchwalenia stosownych ustaw, zawarły dotychczas następujące Kościoły i związki konfesyjne: Ewangelicki Kościół Waldensów ${ }^{68}$, Zgromadzenie Boże we Włoszech ${ }^{69}$, Kościół Adwentystów Dnia Siódmego ${ }^{70}$, Związek Włoskich Gmin Żydowskich ${ }^{71}$, Chrześcijańska Unia Ewangelicko-Baptystyczna Włoch ${ }^{72}$, Kościół Ewangelicko-Luterański we Włoszech ${ }^{73}$, Metropolia Włoska i Egzarchat Europy Sródziemnomorskiej ${ }^{74}$, Kościół Jezusa Chrystusa Świętych w Dniach Ostatnich (mormoni) ${ }^{75}$,

${ }^{68}$ Zob. Legge 449/1984 Norme per la regolazione dei rapporti tra lo Stato e le chiese rappresentate dalla Tavola valdese (GU n. 222 del 13-8-1984); Legge 409/1993 Integrazione dell'intesa tra il Governo della Repubblica italiana e la Tavola valdese, in attuazione dell'articolo 8, terzo comma, della Costituzione (GU n. 239 del 11-10-1993).

${ }^{69}$ Zob. Legge 517/1988 Norme per la regolazione dei rapporti tra lo Stato e le Assemblee di Dio in Italia (GU n. 283 del 2-12-1988 - Suppl. Ordinario n. 107).

${ }^{70}$ Zob. Legge 516/1988 Norme per la regolazione dei rapporti tra lo Stato e l'Unione italiana delle Chiese cristiane avventiste del $7^{\circ}$ giorno (GU n. 283 del 2-12-1988 - Suppl. Ordinario n. 107); Legge 637/1996 Modifica dell'intesa tra il Governo della Repubblica italiana e l'Unione italiana delle Chiese cristiane avventiste del 7 giorno, in attuazione dell'articolo 8, comma terzo, della Costituzione (GU n. 299 del 21-12-1996).

${ }^{71}$ Zob. Legge 101/1989 Norme per la regolazione dei rapporti tra lo Stato e l'Unione delle Comunita' ebraiche italiane (GU n. 69 del 23-3-1989 - Suppl. Ordinario n. 21).

72 Zob. Legge 116/1995 Norme per la regolazione dei rapporti tra lo Stato e l'Unione Cristiana Evangelica Battista d'Italia (UCEBI). (GU n. 94 del 22-41995 - Suppl. Ordinario n. 46).

${ }^{73}$ Zob. Legge 520/1995 Norme per la regolazione dei rapporti tra lo Stato e la Chiesa Evangelica Luterana in Italia (Gazz. Uff. 7 dicembre 1995, n. 286).

${ }^{74}$ Zob. Legge n. 126/12 Norme per la regolazione dei rapporti tra lo Stato e la Sacra arcidiocesi ortodossa d'Italia ed Esarcato per l'Europa Meridionale, in attuazione dell'articolo 8, terzo comma, della Costituzione (12G0145) (GU n. 183 del 7-8-2012 - Suppl. Ordinario n. 168).

75 Zob. Legge n. 127/12 Norme per la regolazione dei rapporti tra lo Stato e la Chiesa di Gesu' Cristo dei Santi degli ultimi giorni, in attuazione dell'articolo 8 , terzo comma, della Costituzione (12G0146) (GU n.1 83 del 7-8-2012 - Suppl. Ordinario n. 168). 
Kościół Zielonoświątkowców Apostolskich we Włoszech ${ }^{76}$, Włoska Unia Buddyjska ${ }^{77}$ i Włoska Unia Hinduistyczna ${ }^{78}$.

Część Kościołów i związków konfesyjnych zawarła później porozumienia uzupełniające lub modyfikujące pierwotne umowy. W odniesieniu do pozostałych związków wyznaniowych należy stosować ustawę o kultach dopuszczonych ${ }^{79}$. Istnieją także związki wyznaniowe, które co prawda zawarły porozumienia $z$ państwem, jednak jeszcze nie zostały na ich podstawie uchwalone ustawy indywidualne. W sytuacji tej znajduje się obecnie Chrześcijańska Kongregacja Świadków Jehowy, która zawarła porozumienie z Republiką 4 kwietnia 2007 roku $^{80}$.

Zazwyczaj związki wyznaniowe zawierają w porozumieniach z władzami państwowymi kompetencję tych drugich do sporządzenia projektu ustawy na podstawie porozumienia, $\mathrm{z}$ zastrzeżeniem dla związku konfesyjnego możliwości żądania konsultacji ${ }^{81}$. W znaczący sposób ułatwia to procedurę legislacyjną. Jest to przykład dla polskiej Rady Ministrów, jak należałoby zawierać umowy ze związkami wyznaniowymi, żeby nadać im atrybut maksymalnej efektywności.

Podmiotem uprawnionym do prowadzenia negocjacji ze związkami wyznaniowymi jest podobnie jak w Polsce - Rząd Republiki. Analogiczny jest także problem braku szczegółowej regulacji procesu kształtowania porozumień ze związkami konfesyjnymi.

${ }^{76}$ Zob. Legge n. 128/12 Norme per la regolazione dei rapporti tra lo Stato e la Chiesa apostolica in Italia, in attuazione dell'articolo 8, terzo comma, della Costituzione (12G0147) (GU n. 183 del 7-8-2012 - Suppl. Ordinario n. 168).

77 Zob. Legge n. 245/12 Norme per la regolazione dei rapporti tra lo Stato e l'Unione Buddhista Italiana, in attuazione dell'articolo 8, terzo comma, della Costituzione (13G00015) (GU n.14 del 17-1-2013).

${ }^{78}$ Zob. Legge n. 246/12 Norme per la regolazione dei rapporti tra lo Stato e l'Unione Induista Italiana, Sanatana Dharma Samgha, in attuazione dell'articolo 8, terzo comma, della Costituzione (13G00017) (GU n.14 del 17-1-2013).

${ }^{79}$ Zob. Legge n. 1159/1929.

${ }^{80}$ Lista porozumień między Kościołami i związkami wyznaniowymi a Republiką Włoską oraz wskazanie ustaw indywidualnych wydanych na ich podstawie jest dostępna w internecie pod adresem: www.governo.it/Presidenza/USRI/ confessioni/intese_indice.html\#2 (dostęp: 1 kwietnia 2014 r.)

${ }^{81}$ Por. P. Stanisz, Udział związków wyznaniowych, w: Funkcje publiczne związków wyznaniowych, red. A. Mezglewski, Lublin 2007, s. 113-132. 


\section{Podsumowanie}

Kształtowanie stosunków pomiędzy państwem a niekatolickimi związkami wyznaniowymi w drodze umów zawieranych na podstawie art. 25 ust. 5 Konstytucji RP i art. 8 zd. 3 Konstytucji Republiki Włoskiej jest oparte na podobnych zasadach. Polskie przepisy w wyraźny sposób zostały bowiem zainspirowane regulacjami włoskimi.

Doświadczenia Republiki pokazują, że zasada bilateralizmu w stosunkach państwa $z$ Kościołami i innymi związkami wyznaniowymi jest rozwiązaniem efektywnym. System ten jest na tyle elastyczny, że może ewoluować na przestrzeni czasu. Zakłada możliwość przystąpienia do niego wszystkich związków wyznaniowych, niezależnie od ich liczebności i tradycji.

Fakt, że od 1997 roku żaden ze związków wyznaniowych zarejestrowanych $\mathrm{w}$ Polsce nie zawarł umowy $z$ Radą Ministrów, jest niepokojący. Jednak biorąc pod uwagę liczbę związków wyznaniowych, których relacje $z$ państwem są regulowane $\mathrm{w}$ drodze ustaw indywidualnych, trzeba zauważyć, że w Polsce jest ich więcej niż we Włoszech.

Wydaje się, że zarówno w Polsce, jak i we Włoszech należy uchwalić przepisy dotyczące wszczęcia, prowadzenia i zamknięcia negocjacji, które jasno określiłyby obowiązki Rady Ministrów oraz konsekwencje jej działań i zaniechań. Aktualna dowolność nie będzie sprzyjać skuteczności opisanych regulacji. Co więcej, może skutkować wprowadzeniem elementu gry politycznej do procesu negocjacyjnego, a to należy uznać za niedopuszczalne.

Chociaż relacje państwa $z$ Kościołami i związkami wyznaniowymi są uregulowane w sposób bilateralny, nadal pojawiają się problemy związane $z$ ich działalnością, zarówno w Polsce, jak i we Włoszech. Wystarczy wspomnieć o problemie obecności symboli religijnych w przestrzeni publicznej, który we Włoszech pojawił się przy okazji sprawy Lautsi przeciwko Republice Włoskiej ${ }^{82}$, a w Polsce w od-

${ }^{82}$ Zob. Wyrok Europejskiego Trybunału Praw Człowieka z 3 listopada 
niesieniu do krucyfiksu wiszącego w sali posiedzeń Sejmu RP ${ }^{83}$. Tego typu spory pokazują, jak bardzo kontrowersyjnym zagadnieniem jest funkcjonowanie związków wyznaniowych w przestrzeni publicznej. Są też jawnym dowodem na to, że związki religii z polityką nadal są silne i trudno ich całkowicie uniknąć. W Polsce we Włoszech więzi te są niezwykle silne i bywają punktem zapalnym $\mathrm{w}$ wielu dyskusjach politycznych.

Obserwując prace związane $z$ wprowadzaniem nowego systemu finansowania związków wyznaniowych, który miałby przenieść odpowiedzialność za wpływy finansowe $z$ budżetu państwa na wiernych, trzeba zauważyć, że dwustronność i partnerstwo w relacjach między państwem a Kościołami i związkami wyznaniowymi udowodniły już swoją skuteczność. Udało się bowiem dojść do porozumienia w sprawie wysokości odpisu podatkowego $(0,5 \%)$. Nietrudno jednak zauważyć, że decydujący głos w dyskusji na ten temat należał do Kościoła katolickiego, a pozostałym związkom wyznaniowym pozostało jedynie przystać na jego ustalenia $z$ rządem $w$ tej sprawie.

Na koniec warto zauważyć, że bilateralizm w stosunkach państwa ze związkami wyznaniowymi w obydwu omawianych krajach nadal jest w fazie rozwoju. Dlatego warto obserwować proces rozpowszechniania tego modelu na coraz więcej związków konfesyjnych oraz ewolucję przepisów, które go regulują. Tym bardziej że polska procedura zawierania porozumień i umów ze związkami wyznaniowymi oraz obowiązki Rady Ministrów w ramach procesu negocjacji i wnoszenia projektu ustawy do Parlamentu, wymagają wprowadzenia dodatkowych regulacji, które prowadzić będą do większej przejrzystości procedur oraz możliwości wyciągania konsekwencji z zachowań i zaniechań Rady Ministrów.

2009 roku oraz Wyrok Wielkiej Izby Europejskiego Trybunału Praw Człowieka z 18 marca 2011 roku.

${ }^{83}$ Zob. Wniosek poselski o wydanie zarządzenia nakazującego usunięcie krzyża łacińskiego, znajdującego się w sali posiedzeń Sejmu Rzeczypospolitej Polskiej z 17 listopada 2011 roku. 


\section{STRESZCZENIE}

Kształtowanie stosunków pomiędzy państwem a niekatolickimi związkami wyznaniowymi w drodze umów zawieranych na podstawie art. 25 ust. 5 Konstytucji Rzeczypospolitej Polskiej i art. 8 zd. 3 Konstytucji Republiki Włoskiej

Autorka artykułu omawia zagadnienie umów zawieranych przez państwo z niekatolickimi związkami wyznaniowymi na podstawie przepisów konstytucji. Jej głównym celem jest wskazanie podobieństw między regulacją zastosowaną w Konstytucji Rzeczypospolitej Polskiej i w Konstytucji Republiki Włoskiej, które są oparte na tych samych zasadach. Dowodem na poparcie tezy jest szeroko omawiane zagadnienie bilateralizmu w stosunkach ze związkami wyznaniowymi, a zwłaszcza w stosunkach z niekatolickimi związkami konfesyjnymi. Podobieństwa są skutkiem wzorowania się polskiego ustawodawcy na regulacjach włoskich. Doświadczenia Republiki pokazały bowiem, że zasada bilateralizmu jest rozwiązaniem efektywnym. System ten jest na tyle elastyczny, że może ewoluować na przestrzeni czasu. Zakłada też możliwość przystąpienia do niego wszystkich związków wyznaniowych, niezależnie od ich liczebności i tradycji.

Słowa kluczowe: bilateralizm, relacje państwo-niekatolickie związki wyznaniowe, autonomia wewnętrzna związków wyznaniowych.

\section{SUMMARY}

Creating relations between state and non-catholic religious confessions by method of agreements concluded on the basis of art. 25 paragraph 5 of the Constitution of the Republic of Poland and art. 8 sentence 3 of the Italian Republic Constitution

The author of the study addresses the problem of agreements between state and non-catholic religious confessions concluded on the constitutional basis. The main aim is to prove similarities of denominational regulations in the Republic of Poland and The Italian Republic, which are founded on the same grounds. Especially, general principle of bilateral relations. The reason of this comparison is, that the Polish legislator was following Italian's example. The principle of cooperation with religious confessions, 
points the internal autonomy that has been given to religious confessions and the granted partner status which reveals during negotiations with the authorities. Italian Republic experience indicates, that the principal of bilateral relations is an effective solution. This system seems to be flexible enough to evaluate in future. It also assumes possibility of accession for all confessions, irrespective of their quantity and traditions.

Keywords: bilateral relations, state-non-catholic religious confessions relations, internal autonomy of religious confessions.

\section{BIBLIOGRAFIA}

Borecki P., Janik C., Komisja Wspólna Przedstawicieli Rządu Rzeczypospolitej Polskiej i Konferencji Episkopatu Polski $w$ archiwaliach $z$ lat 1989-2010, Warszawa 2011.

Cardia C., Stato e confessioni religiose. Il Regime Finanziario, w: Enciclopedia Giuridica, Roma 1993.

Complak K., Relacje między państwem a związkami wyznaniowymi, w: Normy pierwszego rozdziału konstytucji Rzeczypospolitej Polskiej, red S. Kaźmierczyk, Wrocław 2007.

Dammacco G., Le relazioni tra lo Stato e Chiesa nella esperienza italiana, w: Podstawy regulacji stosunków państwo-Kościót w Rzeczypospolitej Polskiej i Republice Włoskiej. I fondamenti della Regolazione delle relazioni stato-chiesa nella Repubblica di Polonia e nella Republica Italiana, red. P. Czarnek, D. Dudek D, Stanisz P., Lublin 2010.

Dzierżanowski A., Z czego żyje Kościót, „Wprost” 13-19 maja 2013.

Finocchiaro F., Stato e Confessioni Religiose. Il Sistema Costituzionale, w: Enciclopedia Giuridica, Roma 1993.

Gaca A., Witkowski Z., Podstawy ustroju konstytucyjnego Republiki Wtoskiej, Toruń 2012.

Garlicki L., Komentarz do art. 25, w: Konstytucja Rzeczypospolitej Polskiej. Komentarz, red. L. Garlicki, t. 5, Warszawa 2007.

Jamróz L., Włochy, w: Systemy ustrojowe państw współczesnych, red.

S. Bożyk, M. Grzybowski, Białystok 2012.

Januchowski A., Zagadnienia zwiazane $z$ interpretacja art. 25 ust. 4 i 5

Konstytucji RP, „Studia z Prawa Wyznaniowego” 2007, t. 10.

Kozerska E., Sytuacja Kościoła katolickiego $w$ faszystowskich Włoszech w latach 1922-1939, w: Cuius regio, eius religio?, red. G. Górski, L. Ćwikła, M. Lipska, Lublin 2006.

Krukowski J., Polskie prawo wyznaniowe, Warszawa 2008. 
Kulikowska M., Otto per mille - wtoski system finansowania związków wyznaniowych, „Toruńskie Studia Polsko-Włoskie” 2012, z. 8.

Leszczyński P., Dualny (umowny i ustawowy) tryb regulacji stosunków między państwem a nierzymskokatolickimi wspólnotami religijnymi na podstawie art. 25 ust. 5 konstytucji RP, w: Bilateralizm $w$ stosunkach państwowo-kościelnych, red. M. Bielecki, Lublin 2011.

Leszczyński P. A., [rec.] M. Olszówka, Ustawy wyznaniowe. Art. 25 ust. 5 Konstytucji RP - próba interpretacji, Warszawa 2010, s. 96, „Przegląd Sejmowy" 2011, nr 5 (106).

Lo Giacco M. L., Una valutazione del Concordato tra Italia e Santa Sede a 25 anni dalla sua modificazione, w: Podstawy regulacji stosunków państwo-Kościół w Rzeczypospolitej Polskiej i Republice Włoskiej, red. P. Czarnek, D. Dudek, P. Stanisz, Lublin 2010.

Mikuli P., Ustawy o ograniczonym zakresie przedmiotowym $w$ systemie źródeł prawa w Polsce. Uwagi porzackkujace, „Przegląd Sejmowy” 2012, nr 5 (112).

Orłowski W., Skrzydło W., Ustrój polityczny Republiki Włoskiej, w: Ustroje państw wspótczesnych, red. Skrzydło W., Lublin 2005.

Podstawy regulacji stosunków państwo-Kościót w Rzeczypospolitej Polskiej i Republice Wtoskiej. I fondamenti della Regolazione delle relazioni stato-chiesa nella Repubblica di Polonia e nella Republica Italiana, red. P. Czarnek, D. Dudek D, Stanisz P., Lublin 2010.

Sarnecki P., Ustroje konstytucyjne państw współczesnych, Warszawa 2013. Stanisz P., Porozumienia $w$ sprawie regulacji stosunków między państwem i niekatolickimi zwiazkami wyznaniowymi we wtoskim porządku prawnym, Lublin 2007.

Stanisz P., Proces normowania stosunków pomiędzy państwem a niekatolickimi zwiazkami wyznaniowymi $w$ trybie art. 8 ust. 3 Konstytucji Republiki Włoskiej z 1947 r. (ujęcie historyczne), „Studia z Prawa Wyznaniowego" 2006, t. 9.

Stanisz P., Stosunki między państwem a kościołami i innymi związkami wyznaniowymi $w$ Rzeczypospolitej Polskiej - zarys problematyki, w: Podstawy regulacji stosunków państwo-Kościół $w$ Rzeczypospolitej Polskiej i Republice Włoskiej, red. P. Czarnek, D. Dudek, P. Stanisz, Lublin 2010.

Stanisz P., Udział związków wyznaniowych $w$ kształtowaniu dotyczącego ich prawa. Doświadczenia włoskie, w: Funkcje publiczne związków wyznaniowych, red. A. Mezglewski, Lublin 2007.

Witkowski Z., Konstytucja Republiki Włoskiej, Warszawa 2004.

Witkowski Z., Konstytucja Republiki Włoskiej, w: Konstytucje państw Unii Europejskiej, red. W. Staśkiewicz, Warszawa 2011. 
Witkowski Z., Opinia $w$ sprawie zagadnień prawnych wynikajacych z art. 25 ust. 5 Konstytucji, „Przegląd Legislacyjny” 2002, nr 24.

Witkowski Z., System konstytucyjny Wtoch, Warszawa 2000.

Witkowski Z., Ustrój konstytucyjny wspótczesnych Włoch w aktualnej fazie jego przemian 1989-2004, Toruń 2004.

Witkowski Z., Wejście w życie Konstytucji Republiki Włoskiej, w: Wejście $w$ życie nowej Konstytucji Rzeczypospolitej polskiej. XXXIX Ogólnopolska Konferencja Katedr Prawa Konstytucyjnego. Księga Pamiątkowa, red. Z. Witkowski, Toruń 1998. 
